\title{
Enhancing public engagement in a fast-paced project environment
}

Thomas Ng BSC, MSc, PhD, RPS (QS)

Professor, Department of Civil Engineering, The University of Hong Kong, Hong Kong

Kelwin Wong BEng, MSc, PhD

Post-doctoral Fellow, Department of Civil Engineering, The University of Hong Kong, Hong Kong
James Wong BSC, PhD

Assistant Manager - Research \& Development, Construction Industry

Council Hong Kong, Hong Kong

Public engagement is becoming increasingly important in the delivery of infrastructure projects. Based on a study conducted in Hong Kong, this paper identifies key challenges in public engagement for infrastructure projects in a region of fast-paced project environments. It proposes a series of recommendations for improving existing practices and presents a roadmap for implementing them. The study involves the review of existing practices and project cases in Hong Kong as well as other countries, and a series of interviews with industry experts who have significant experience in public engagement for infrastructure projects.

\section{Introduction}

In response to the 2008 global financial crisis, governments around the world dedicated significant efforts and resources to revive their countries' economies. Government spending on construction and infrastructure projects is often considered to be a crucial part of any significant economic stimulus package.

The US government presented a US\$140 billion plan directed towards transportation and infrastructure spending as part of its stimulus package (The New York Times, 2011), while the Chinese government released a RMB $\$ 4$ trillion (US\$610 billion) stimulus package with a significant portion for construction and infrastructure investment (Yuen and Greene, 2011). With substantial public money being spent on these infrastructures, addressing societal needs, and improving transparency and public accountability are of paramount importance (Shan and Yai, 2011).

Although some cities are considered economically advanced or politically matured, this does not always translate into social satisfaction, particularly when the public feels that their needs and concerns have not been adequately addressed by the government. Properly engaging the public not only enables decision-makers to gain a better perspective on public needs, but may also provide them with more ideas and useful knowledge that can be implemented into the projects.

However, rather than being a continuous process, mechanisms for encouraging public participation such as forums, exhibitions and surveys are usually only part of the planning phase within a project (Tsang et al., 2009). Public engagement is also equally important during the construction, operation and usage phases of a project (as highlighted in case examples from Canada and Australia later in this paper).

Public engagement programmes can often account for significant time within a project schedule (CEDD, 2013; InTransit $\mathrm{BC}, 2006)$. Ineffective public engagement can lead to public opinions or concerns not being sufficiently addressed in the planning of the project, thus not fully delivering the best value or benefits possible for end-users. It can also cause project delays and cost overruns (Anon, 2007a; Broudehoux, 2007; Kidd, 1992; Lam, 2009; Lenskyj, 1999). This is made even more important in a setting where the pace of projects is rapid and project deadlines are tight.

Hong Kong is a good example of a city with this type of fastpaced project environment. In his 2007 policy address, former chief executive Donald Tsang expressed his commitment to expedite the previously announced ten major infrastructure projects to 'foster further cross-boundary integration' and 'consolidate Hong Kong's status as a global city and lay a new foundation for our sustained development in the future' (Chief Executive Office of the Hong Kong SAR government, 2007; Yuen, 2012).

By identifying key challenges and systematically capturing lessons learned from previous projects, decision-makers of infrastructure projects and those conducting public engagement exercises can target those specific areas, thereby being able to plan for a more efficient and effective programme, and make improvements for subsequent projects (as illustrated in Figures 1 and 2).

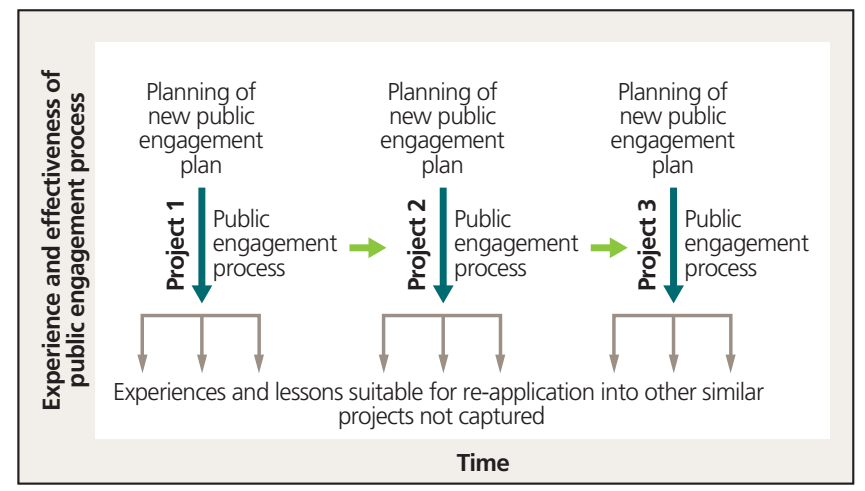

Figure 1. Loss of lessons learned during public engagement processes 


\section{Offprint provided courtesy of www.icevirtuallibrary.com Author copy for personal use, not for distribution}

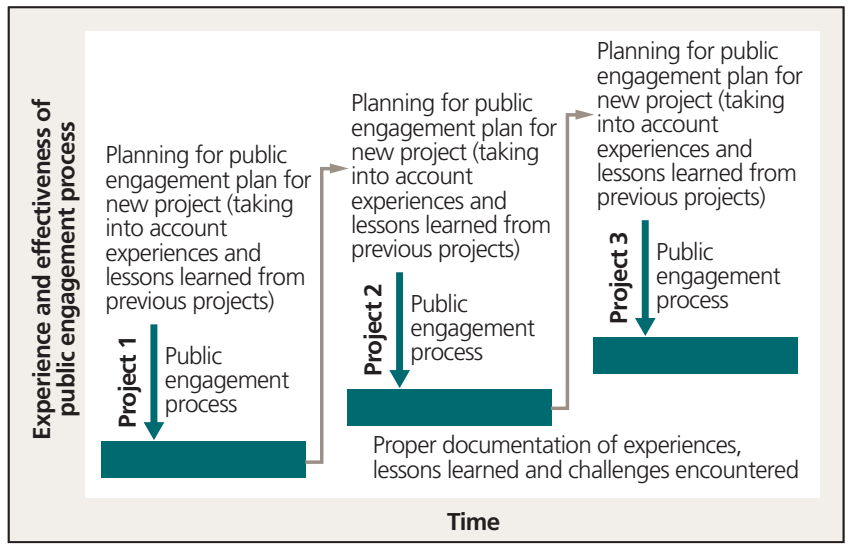

Figure 2. Capturing lessons learned for better planning of public engagement processes in subsequent projects

The aims of this paper are to identify common problem areas in public engagement for infrastructure projects in regions with fast-paced project environments such as Hong Kong, put forth a series of recommendations for enhancing public engagement and present a roadmap for implementing these recommendations. The emphasis in this paper is on infrastructure projects, because of their significant use by (and therefore impact on) the general public, which highlights the importance of public engagement processes.

\section{Research methods}

\subsection{Review of local practices and project cases}

A review of existing public engagement practices for construction and infrastructure projects in Hong Kong was conducted to gain solid understanding of the current status of public engagement in Hong Kong, prepare for interviews with industry experts and make meaningful comparisons with other regions in the subsequent stages of the investigation. Government policies, research reports and working papers related to public engagement exercises were among the materials reviewed. Furthermore, two project cases in Hong Kong were studied to uncover the challenges and difficulties in public engagement processes and identify the potential lessons learned that could be relevant to future projects of a similar nature.

\subsection{Interviews with industry experts}

To acquire more in-depth insights into public engagement practices in Hong Kong, and to identify the current shortfalls and challenges so as to pave the way for deriving improvement measures, 15 semi-structured interviews were carried out with local experts (from the government, private sector and district council) who have significant experience and knowledge of public engagement for construction and infrastructure projects. A breakdown of the interviewees is shown in Table 1. The topics covered in the interviews include: the current status of public engagement processes in Hong Kong; the stages of a project where public consultation should be conducted; methods of consultation; measuring, analysing and evaluating public opinions; and safeguarding stakeholder interests.

\begin{tabular}{|lll|}
\hline Interviewee & Category & Position \\
\hline 1 & Government & Deputy director \\
\hline 2 & Government & Chief architect \\
\hline 3 & Government & Project engineer \\
\hline 4 & Government & Assistant director \\
\hline 5 & Private (consultant) & Director \\
\hline 6 & Private (consultant) & Project manager \\
\hline 7 & Private (consultant) & Director \\
\hline 9 & Private (consultant) & Director \\
\hline 10 & Private (consultant) & Associate director \\
\hline 11 & Private (consultant) & Project manager \\
\hline 12 & Professional institutions and organisations & Executive director \\
\hline 13 & Professional institutions and organisations & President \\
\hline 14 & Professional institutions and organisations & Regional director \\
\hline 15 & District council & District councillor \\
\hline
\end{tabular}

Table 1. Breakdown of interviews conducted

\subsection{Review of overseas project cases}

For more in-depth investigation into regions that are experienced in public engagement, two project cases were examined in Canada and Australia. These two cases were selected because of their success; they serve as a good benchmark for major infrastructure projects involving public engagement, as well as being representative cases of projects with tight deadlines. The Canadian project highlights the significance of public engagement during the design and construction stages, whereas the Australian project underlines the importance of continuous public engagement during the operation and usage stage.

\section{Public engagement in Hong Kong}

The Hong Kong government's commitment towards 'peoplebased governance' was made clear in the 2007-2008 policy address, where it was stated that the government was determined to 'identify what our people need, so as to provide them with more efficient and convenient services'.

With regards to infrastructure projects, it was confirmed that the government will proceed with the ten mega infrastructure projects to 'foster further cross-boundary integration' and 'consolidate Hong Kong's status as a global city and lay a new foundation for our sustained development in the future' (Chief Executive Office of the Hong Kong SAR government, 2007). With substantial public money going to these projects, inevitably there will be pressure on the government to increase accountability to the people, improve public satisfaction, gain support from communities and maximise social benefits for these projects.

Although Hong Kong is often perceived as one of the more advanced and developed cities in South East Asia, the city's experience in public engagement is still very limited, taking shape only within the past 10 years (brought about by a cultural shift towards greater public participation in general for policy decision-making) according to some of the experts interviewed. 


\section{Offprint provided courtesy of www.icevirtuallibrary.com Author copy for personal use, not for distribution}

One of the interviewees in particular (an experienced district councillor) pointed out that there was very limited public engagement prior to the 1997 handover of Hong Kong back to Chinese rule (when Hong Kong was under British rule).

In fact, since the 1997 handover the Hong Kong government has been emphasising the need to focus on public sentiment and a 'Hong Kong people administering Hong Kong's approach to governance' (HKSAR, 2002, 2015). Thus, Hong Kong is now playing catch-up to countries such as Canada and Australia (as well as other developed countries) when it comes to public engagement.

Inadequate leadership, lack of accountability and transparency, and insufficient dialogue with the public were considered by Burnett et al. (2008) to be the main contributing factors that adversely affect public trust in a government. Actions from the Hong Kong government are often magnified in the local media, thus attracting much attention from the general public (Lee, 2009), and in recent years the local population have become increasingly vocal in expressing their views (Chu, 2010). The Queen's Pier relocation and the Hong Kong section of the GuangzhouShenzhen-Hong Kong express railway link (XRL) projects were two such examples.

The Queen's Pier relocation project was part of the third phase of the Central reclamation project. The old pier was considered to be rich in history and symbolic of the British colonial era in Hong Kong, dating back to 1925, and served as the arrival point for many of Hong Kong's governors (Figure 3). The pier was to be relocated along the waterfront on reclaimed land, but stern opposition from groups including the Conservancy Association, Society for Protection of the Harbour and the Hong Kong Institute of Architects caused the dismantling work to be significantly postponed (Parwani, 2007).

Protesters rallied at the site and several students went on a hunger strike prior to the old pier being closed down (Anon, 2007a). In response to the protests, dismantling of the old pier was postponed, but government officials reiterated that dismantling of the old pier must take place. Subsequently, the government decided on a piece-by-piece relocation plan to dismantle the old pier and

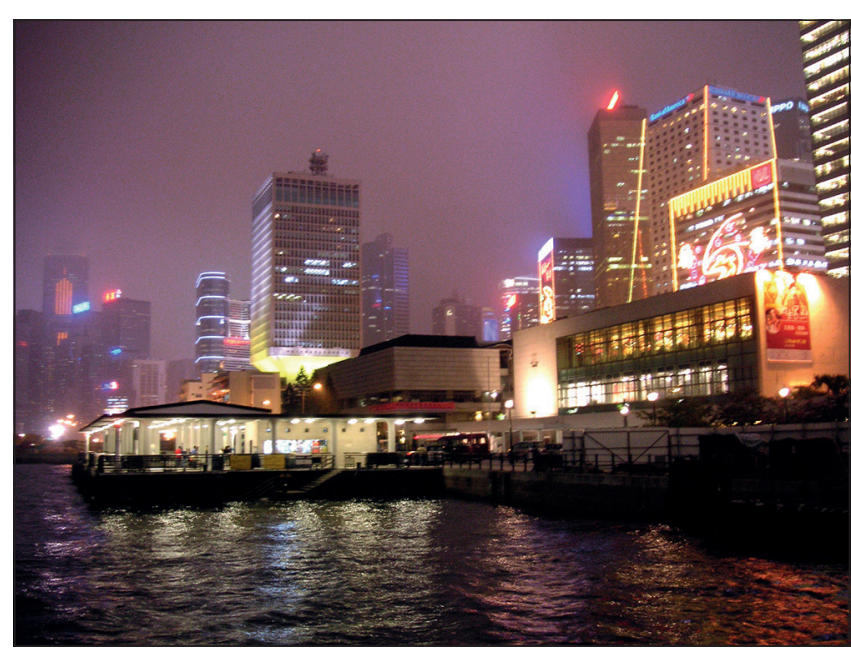

Figure 3. Queen's Pier in Hong Kong shortly before it was demolished in 2008 (CC BY-SA 2.5, see https://commons.wikimedia.org/w/index. php?curid=524247) reassemble it at a new location on the reclaimed waterfront land (Anon, 2007b). This incident reflected the deficiency of the local public engagement process (Yung and Chan, 2011).

Another controversial project was the XRL project, which connects Hong Kong to the railway network in the Guangdong province (Figure 4). The project's high cost of over HK $\$ 80$ billion ( $£ 7.2$ billion), the need to relocate residents from a farming village in the path of the railway plan, and potential noise pollution in some districts along the railway route were among the main causes of opposition. Public consultation for this project was poorly timed and badly managed (Hayllar, 2010). As a result, during the debate for funding in December 2009, major protests took place outside the legislative council (Lam, 2009), and close to 1000 protestors stood outside Government House to display their condemnation of the project just before the budget approval in January 2010 (Anon, 2010a).

Moreover, a group of young people (known as the 'Post 80s Anti-Express Railway Group' - with 'Post 80s' referring to those who were born after 1980) held demonstrations both at the legislative council and at the village when the bulldozers arrived, in defence of the villagers (Mok, 2010). In spite of the protests, legislators finally approved funding for the project in mid-January 2010, recognising its overall strategic importance to Hong Kong and the need for integration with the broader railway network in China (Hong Kong Legislative Council, 2010). However, opposition to the project had already led to two separate delays, as it was initially planned that construction would begin in late 2009 . This was yet another example showing that there is an urgent need to explore more effective ways of consulting the public for future large-scale infrastructure projects.

The next section will look into public engagement practices for major infrastructure projects in Australia and Canada, where projects also needed to be completed in a timely manner, facing tight schedules and time constraints. It would be regrettable if such valuable experiences are not extracted and the key success elements applied to other projects in cities such as Hong Kong.

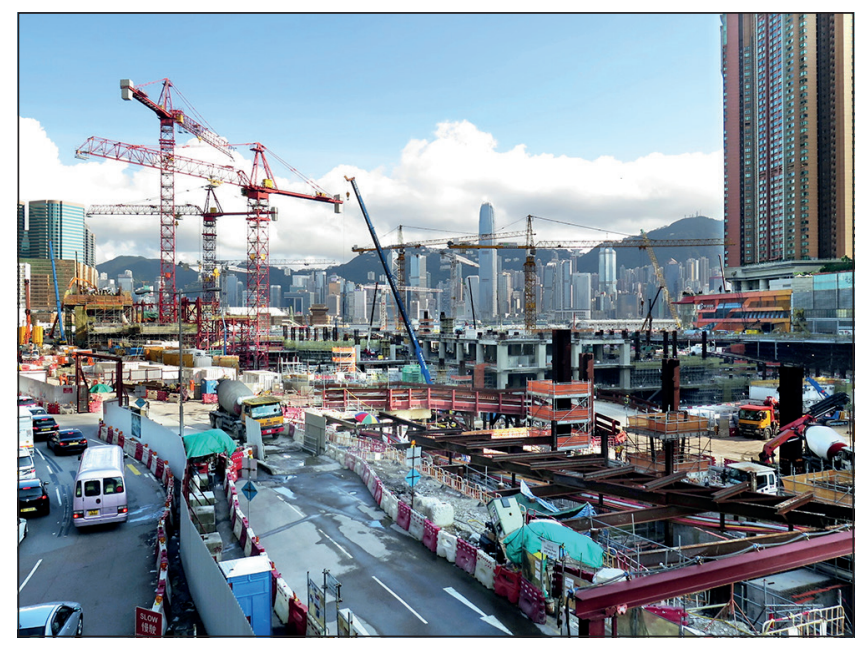

Figure 4. Construction site of West Kowloon terminus of the Guangzhou-Shenzhen-Hong Kong express rail link, which is due for completion in 2018 (By Wing1990hk (own work) (CC BY 3.0 (http://creativecommons.org/licenses/by/3.0)), via Wikimedia Commons) 


\section{Offprint provided courtesy of www.icevirtuallibrary.com Author copy for personal use, not for distribution}

\section{Public engagement in Australia and Canada}

\subsection{Canada Line, Vancouver, Canada}

The Canada Line project was a $19 \mathrm{~km}, \mathrm{CAN} \$ 1.9$ billion ( $£ 940$ million) railway project with 16 stations, linking two cities (Vancouver and Richmond) to Vancouver International Airport, built to coincide with the 2010 Winter Olympics in Vancouver, Canada (Figure 5). It was funded using a public-private partnership mode (InTransit BC, 2010). The project was considered a success as it was completed more than 3 months ahead of schedule and within budget.

With major sporting events like the Olympics, the construction of the infrastructure projects needed to host these events often faces immovable deadlines and involves multiple projects taking place concurrently (transportation, stadiums, accommodation for athletes and tourists, and so on) (Fedorovsky et al, 2013; Ormsby, 2011). All of this has a significant impact on the local residents of the host cities. Moreover, how these infrastructure projects will be used by the local population after the sporting events have been completed, and how they fit with the local landscape, are important issues to be considered (Broudehoux, 2007; Kidd, 1992; Lenskyj, 1999).

During the course of the project, a comprehensive public engagement programme was implemented with a series of events conducted between February 2003 and June 2006. The public engagement programme consisted of four stages and each stage of the programme was carried out in parallel with a particular phase of the design process. Furthermore, each stage was results oriented, with a specific focus, and targeted a particular aspect of the project. The specific focus of each stage yielded specific results and decisions that helped to guide the process along so that it could proceed to the next stage. Details of the engagement process at each project stage, timeframe and focus are shown in Table 2.

The well-structured and results-oriented public engagement plan made the process more efficient than simply going to the public with a blank sheet to ask them what they wanted, and contributed significantly to the overall success of the project, as it added much value with quality feedback from the public. Having a public engagement process that spans multiple stages of a project allowed the project team and the public to focus on certain aspects

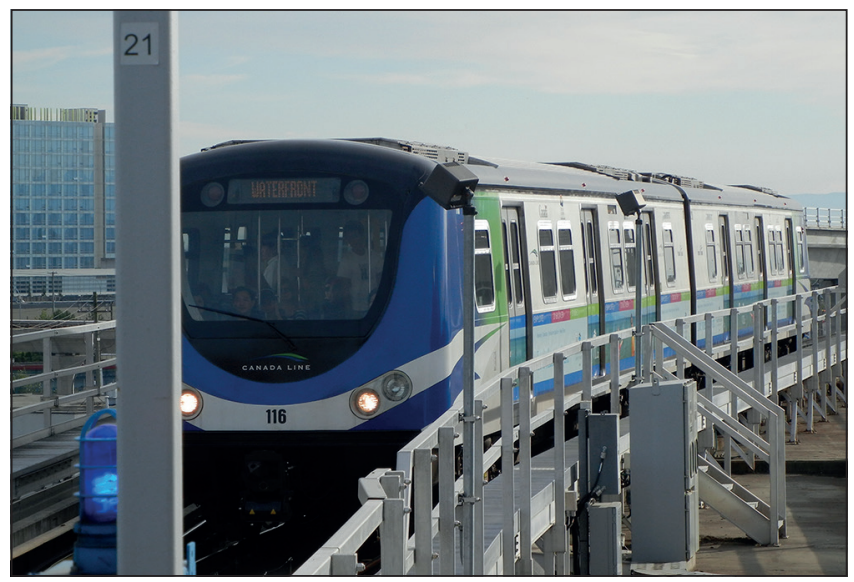

Figure 5. Bridgeport station on the Canada Line in Vancouver, Canada, which opened in 2009 (by Jeremy Andrews (own work) (CC BY-SA 3.0, see http://creativecommons.org/licenses/by-sa/3.0), via Wikimedia Commons)

\begin{tabular}{|c|c|c|}
\hline $\begin{array}{l}\text { Project } \\
\text { stage }\end{array}$ & $\begin{array}{l}\text { Timeframe } \\
\text { of public } \\
\text { consultation }\end{array}$ & Consultation focus \\
\hline $\begin{array}{l}\text { Project } \\
\text { definition }\end{array}$ & $\begin{array}{l}\text { February-May } \\
2003\end{array}$ & $\begin{array}{l}\text { Basic system elements - proposed alignment, } \\
\text { access, travel times, underground works, at } \\
\text { street level as opposed to elevated system, } \\
\text { and cost. Result: decision to proceed }\end{array}$ \\
\hline Pre-design & $\begin{array}{l}\text { October 2003- } \\
\text { April } 2004\end{array}$ & $\begin{array}{l}\text { Design objectives related to station access } \\
\text { and connections, safety and security, system } \\
\text { design and station identity, stations in } \\
\text { neighbourhoods and train guideway. Result: } \\
\text { identification of seven key design objectives }\end{array}$ \\
\hline $\begin{array}{l}\text { Preliminary } \\
\text { design }\end{array}$ & June 2005 & $\begin{array}{l}\text { Specific elements of station design including } \\
\text { station entrances, how station designs might } \\
\text { reflect the local neighbourhood and how } \\
\text { people get to the stations }\end{array}$ \\
\hline $\begin{array}{l}\text { Detailed } \\
\text { design }\end{array}$ & $\begin{array}{l}\text { January-June } \\
2006\end{array}$ & $\begin{array}{l}\text { Fewer but very specific treatments related } \\
\text { to access, lighting, landscaping and other } \\
\text { considerations }\end{array}$ \\
\hline \multicolumn{3}{|c|}{ Source: InTransit BC (2006) } \\
\hline
\end{tabular}

Table 2. Canada Line public consultation timeline

of the project at a particular stage and make the convergence of ideas possible, so as to arrive at mutually beneficial solutions and decisions for all sides.

Transparency and access of information also played a vital role in the success of the public engagement process. Although public forums and workshops are commonly conducted in other projects, it is often difficult for the public to understand how their opinions or concerns have been considered. In this project, opinions and concerns from the public were well documented and decisions were explained in detail.

Response tables were made to explain how the issues raised by stakeholders were addressed or why some of suggestions could not be implemented (owing to technical, environmental or financial constraints, and so on), with detailed reasoning to support the decisions made. Examples of the comments, opinions and questions raised by the public are highlighted in Table 3 .

\subsection{City Link, Melbourne, Australia}

City Link is an electronic toll route in Melbourne, Australia, with a combined length of $22 \mathrm{~km}$, linking four of the city's freeways (Figure 6). The project provides vital strategic links between the Melbourne airport and industrial centres in south-east Melbourne. Thus, the project's impact on commuters is significant. Roadwork construction, traffic detours, and repair and maintenance work all have to be completed on a timely basis to mitigate the impact and inconveniences to road users (Government of Victoria, 2008; Kaur, 2014).

Transurban Group (owner and operator of the project) recognised that community engagement has become increasingly important during construction (Transurban, 2009), and worked closely with stakeholders such as the government, communities and customers throughout the life of the toll road project. Continuous engagement during the operation/usage phase of a project is important for major infrastructure projects such as City Link owing to the long service life and expected upgrades (and thus long-term impact on society). It can also help to improve service quality by maintaining a channel of communication with end-users. 


\section{Offprint provided courtesy of www.icevirtuallibrary.com Author copy for personal use, not for distribution}

\begin{tabular}{|c|c|}
\hline $\begin{array}{l}\text { Comments, } \\
\text { opinions and } \\
\text { questions }\end{array}$ & $\begin{array}{l}\text { Response from Richmond-Airport-Vancouver } \\
\text { Rapid Transit }\end{array}$ \\
\hline $\begin{array}{l}\text { Feasibility of } \\
\text { stacking two } \\
\text { guideways along a } \\
\text { road as part of the } \\
\text { system layout }\end{array}$ & $\begin{array}{l}\text { Such an option 'has not been pursued as it would } \\
\text { require greater costs, and impose a greater urban } \\
\text { design impact to the streetscape and adjacent } \\
\text { developments' (Ravco, 2005: p. 5) }\end{array}$ \\
\hline $\begin{array}{l}\text { Concerns about } \\
\text { the environmental } \\
\text { impact from the } \\
\text { tunnel construction } \\
\text { degrading the goal } \\
\text { of establishing } \\
\text { a sustainable } \\
\text { community }\end{array}$ & $\begin{array}{l}\text { References were made to previously compiled planning } \\
\text { reports (namely the RAV project environmental } \\
\text { management plan and the Greater Vancouver regional } \\
\text { district liveable region strategic plan) to highlight that } \\
\text { the measure taken 'complies with all applicable federal } \\
\text { and provincial legislative and regulatory requirements; } \\
\text { local government by-laws; and, best management } \\
\text { practices' (Ravco, 2005: p. 4) and that it supports the } \\
\text { initiatives outlined in the plans to 'reduce the volume } \\
\text { of vehicle traffic, traffic congestion and associated } \\
\text { adverse environmental and socio-community impacts' } \\
\text { (Ravco, 2005: p. 5) }\end{array}$ \\
\hline $\begin{array}{l}\text { No fisheries or } \\
\text { aquatic assessment } \\
\text { was prepared or } \\
\text { presented and this } \\
\text { was an area of } \\
\text { concern because } \\
\text { of the tunnel } \\
\text { boring through the } \\
\text { bedrock under the } \\
\text { subsurface stream } \\
\text { beds }\end{array}$ & $\begin{array}{l}\text { Reference was made to the fisheries and aquatic } \\
\text { habitat assessment completed as part of the } \\
\text { environmental assessment certificate (EAC) application } \\
\text { process to be submitted to the provincial government, } \\
\text { which 'identifies and addresses potential impacts } \\
\text { to remnant subsurface streams and the Fraser } \\
\text { River crossings' (Ravco, 2005: p. 4). Furthermore, } \\
\text { 'three historical watercourses were identified in the } \\
\text { South Vancouver portion of the Richmond-Airport- } \\
\text { Vancouver rapid transit project area and, with the } \\
\text { exception of a relict open channel of Winona Creek } \\
\text { within the southern portion of the Langara Golf } \\
\text { Course, these are now entirely enclosed within piped } \\
\text { sewer systems', and that 'project construction will not } \\
\text { significantly affect fish habitat' (Ravco, 2005: p. 4). } \\
\text { Specific EAC application sections were cited to add } \\
\text { further credibility to the response }\end{array}$ \\
\hline & \\
\hline
\end{tabular}

Table 3. Examples of comments from public and responses from Richmond-Airport-Vancouver rapid transit

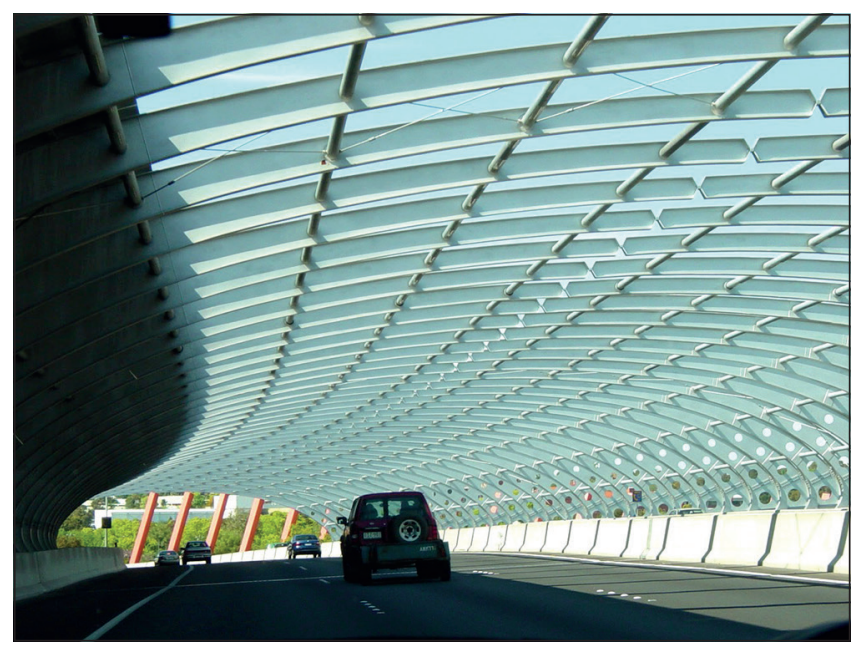

Figure 6. Flemington noise barrier on the City Link tolled motorway network in Melbourne, Australia, which opened in 1999 (by Atlantica (en wiki) (GNU Free Documentation License, see http://www.gnu.org/ copyleft/fdl.html or CC-BY-SA-3.0, see http://creativecommons.org/ licenses/by-sa/3.0/), via Wikimedia Commons)
The independent customer ombudsman was introduced by Transurban in 2004 to provide a channel for users to express their comments, dissatisfaction and complaints, with a formal resolution process. A customer ombudsman report is periodically released, and City Link has agreed to be bound by the ombudsman's decision on customer complaints. In addition, City Link's customer charter commitments are compiled every 6 months. Both reports are made available to the public to ensure greater transparency in the process.

In 2009, an extensive community outreach programme was undertaken to inform stakeholders about the high-occupancy toll lanes upgrade project. Communications programmes for ongoing construction works were also done for the Southern Link upgrade. Through an evaluation process on the project team's communication with stakeholders regarding construction work for the upgrade project, where 19 stakeholder groups were engaged in the process, it was found that $60 \%$ of stakeholders were satisfied with the project team's communication.

The stakeholder groups included representatives from a wide spectrum of groups including local councils, environmental groups, transportation bodies, community residents and emergency services (Transurban, 2009). Although a 60\% satisfaction result in communication leaves much room for improvement, reaching out to stakeholders in such a manner can help to maintain a connection between the operator and users, as well as to help rectify problems as soon as they surface.

A dedicated website of the project provides users with up-to-date project information, planned works and road closures, among other features (toll calculation, maps and so on). The project website also provides dedicated phone lines for individuals and business customers, as well as email and postal address for inquiries. Furthermore, collaboration efforts have been made with community groups (residents, environmental groups, schools and so on) and special user groups (cyclists, taxis, bus operators and so on) for managing issues and potential/actual impacts of project operations.

The means of engagement include formal meetings, informal consultation and community events, as well as phone calls, emails and written correspondence. The combination of the initiatives highlighted above demonstrates the operator's dedication to continuous public engagement during the operation and usage phase of the project.

\section{Findings from interviews in Hong Kong}

Fifteen interviews were conducted with experts with significant experience and knowledge of infrastructure management, and/or public engagement to identify current shortfalls and successful ingredients for public engagement practices in Hong Kong. The key findings from these interviews are presented below.

\subsection{Need for a framework}

The vast majority of interviewees (particularly those from the private sector and professional organisations) believed that a structured framework of public engagement for infrastructure projects is lacking in Hong Kong. A framework is advocated to guide the public engagement process in a project which can properly navigate the government, consultants and contractors through the process while offering enough flexibility so that it can be applicable to a broad range of projects. 


\section{Offprint provided courtesy of www.icevirtuallibrary.com Author copy for personal use, not for distribution}

A district council member expressed that, instead of treating public consultations as tokenistic, a certain degree of power should be given to participants under the framework to influence decisions, rather than just giving them the right to know and to express their views.

Based on the previous local experience and successful project cases from outside Hong Kong, institutional and administrative frameworks with adequate legal provision to support the public engagement for infrastructure projects is recommended to be established. In order to develop such a framework, industry stakeholders should be consulted to determine the detailed steps required for each stage of the project process (from planning and design to construction and operation), in order to incorporate the diverse views from the public into decision making so that various stakeholders' objectives and requirements can be better aligned.

\subsection{Early engagement and provision of adequate information}

The timing for launching the public engagement exercise is important and affects the quality and consequences of planning decisions (Alexander, 2008). Most interviewees agreed that public engagement should begin early in the initial project planning stage, as opposed to later in the project when most of the key design decisions have already been made. Early involvement of stakeholders in decision making is crucial to avoid subsequent conflicts.

In addition, several interviewees noted that, with the current practice, the public is not adequately informed and that sufficient project information (for example proposed direction, scope, potential impacts and preliminary design drawings) should be presented to the public prior to the consultation events. Another common scenario is that the government has already made a decision on what they want and consultation is conducted merely to inform the public without leaving much room for changes. Both situations may lead to unproductive and ineffective consultation.

According to two interviewees from the government and a professional organisation, the general public cannot be expected to possess the same knowledge as construction industry professionals. Therefore, it is the responsibility of the party conducting the engagement event (government, private consultant, or third-party consultant) to explain properly the proposed design, associated costs, benefits and impact to the public, reasons behind the decisions made, and most importantly, the limitations (e.g. why certain options are not feasible).

Presentation and promotion of ideas to the public is an area where several interviewees from the private sector and professional organisations and institutions believe much improvement is needed. More specifically, a third-party facilitator specialising in public consultation can help convey project information to the public more effectively and reduce the misconception that the government favours private sector interests.

\subsection{Pre-consultation}

In many cases, strong objections come from minority groups who are either directly affected by a project or have special interests. As reflected by a number of interviewees, properly identifying and engaging these groups (e.g. directly affected residents, activists, environmental and pressure groups, district and legislative council members) early would be crucial.
Bilateral pre-consultation prior to an open public consultation can help project proponents better understand the positions of specific stakeholder groups and appropriate adjustments can be made in advance to accommodate their needs and address highly contended issues before key decisions are made.

An interviewee from the district council agreed that district councillors should play a significant role as a bridge between government and the public during the public engagement process by being more pro-active in providing information to the public on the project plans, collecting public opinions and encouraging public participation.

Pre-consultation can also provide a chance for project proponents to reach out to other stakeholders to determine what role they can (or are willing to) play in the process, to mobilise forces and to allocate necessary resources before the public consultation events. Moreover, pre-consultation with these groups can help gain traction and support for a project ahead of the public engagement process and help to avoid major stalemates, which in turn can speed up the entire process.

\subsection{Employing appropriate methods of engagement and evaluation techniques}

In Hong Kong, public forums and written responses are the frequently used consultation means for infrastructure projects. Many of the interviewees do believe that using questionnaire surveys at the initial stage of the process to seek public opinions would be more effective and convincing, as the data collected can be quantitatively analysed and can provide a general direction in which to proceed with the project.

Public forums, however, should be reserved for subsequent stages of the process, where details of the design can be further discussed. Once public opinions are collected, they can be analysed to determine if these public preferences are within the financial budget of the project and/or comply with the requirements from environmental and technical assessments.

In addition, some interviewees considered that public needs, comments and suggestions from previous projects should serve as background reference for planning future projects rather than starting with a blank sheet for a new project every time. Doing so can help decision-makers better prepare for these new projects, by making more accurate assumptions, and more effectively anticipate potential obstacles that have been previously encountered in similar projects more effectively. This can, in turn, contribute to a focused public engagement plan aimed at tackling specific issues at different stages of a project.

\section{Recommendations and roadmap for enhancing public engagement processes in fast-paced project environments}

Based on the findings from this study, a series of recommendations to enhance public engagement processes in regions with fast-paced project environments has been derived and the roadmap for implementing these recommendations is illustrated in Figure 7. The first step is to study carefully and evaluate public engagement processes of similar previous projects to see what worked and what did not. Although each project is 


\section{Offprint provided courtesy of www.icevirtuallibrary.com Author copy for personal use, not for distribution}

\begin{tabular}{|c|c|c|c|c|c|}
\hline $\begin{array}{c}\text { Study and evaluate } \\
\text { public engagement } \\
\text { processes in previous } \\
\text { projects }\end{array}$ & $\begin{array}{l}\text { Establish framework } \\
\text { for public } \\
\text { engagement }\end{array}$ & Pre-consultation & $\begin{array}{l}\text { Identifying earliest } \\
\text { possible engagement } \\
\text { date }\end{array}$ & $\begin{array}{l}\text { Maintaining dialogue } \\
\text { with affected } \\
\text { groups/parties and } \\
\text { the public } \\
\text { throughout project }\end{array}$ & $\begin{array}{l}\text { Capture experiences } \\
\text { and lessons learned }\end{array}$ \\
\hline $\begin{array}{l}\text { What tends to be the } \\
\text { most sensitive issues? } \\
\text { How can more public } \\
\text { support be gained } \\
\text { and how can public } \\
\text { opposition be } \\
\text { mitigated? }\end{array}$ & $\begin{array}{l}\text { Who are the key } \\
\text { stakeholders? } \\
\text { What means of } \\
\text { engagement to } \\
\text { employ? } \\
\text { How long should the } \\
\text { engagement process } \\
\text { be? } \\
\text { Ensure planned } \\
\text { public engagement } \\
\text { process is } \\
\text { multi-staged and } \\
\text { continuous }\end{array}$ & $\begin{array}{l}\text { Which stakeholders, } \\
\text { interest groups } \\
\text { and/or members of } \\
\text { the public would be } \\
\text { most affected by the } \\
\text { project? } \\
\text { Initiate dialogue with } \\
\text { these parties as } \\
\text { quickly as possible }\end{array}$ & $\begin{array}{l}\text { When can project } \\
\text { information be } \\
\text { shared with the } \\
\text { public? } \\
\text { What are the various } \\
\text { channels for } \\
\text { dissemination of } \\
\text { information? } \\
\text { Commence the } \\
\text { public engagement } \\
\text { process as early as } \\
\text { possible }\end{array}$ & $\begin{array}{l}\text { Provide updates on } \\
\text { project progress, } \\
\text { challenges and how } \\
\text { to mitigate } \\
\text { disruptions, and } \\
\text { encourage joint } \\
\text { problem-solving to } \\
\text { come up with } \\
\text { collaborative } \\
\text { solutions }\end{array}$ & $\begin{array}{l}\text { Ensure proper } \\
\text { documentation and } \\
\text { categorisation of } \\
\text { findings from public } \\
\text { engagement process } \\
\text { Input of records into } \\
\text { database to be kept } \\
\text { and updated by client }\end{array}$ \\
\hline
\end{tabular}

Figure 7. Roadmap for enhancing public engagement processes for fast-paced project environments

different and has its distinct characteristics and challenges, there are still valuable lessons and useful experiences that could serve as important references.

By referring to the project cases, decision-makers can get a better grip on what the most sensitive issues in similar projects tend to be, which groups are the most vocal and how potentially to gain more public support or mitigate public opposition. Next is the need to establish a public engagement framework to ensure that a comprehensive plan can be put in place. There are a number of key questions that need to be addressed (as shown in Figure 7), such as who the key stakeholders are, what means of engagement to employ and how long the engagement process should be.

Pre-consultation is the third recommendation in the roadmap. In the XRL project, residents of the Choi-Yuen village constituted one of the most directly affected groups, whereas conservation and heritage preservation groups were the most sensitive towards the Queen's Pier relocation project. With hindsight, pre-consultation with these stakeholders earlier on potentially could have mitigated the project delays and controversies in the respective projects. Therefore, it is important to identify the most affected groups and initiate dialogue with them as soon as possible.

The fourth step is to determine the earliest date for the public engagement process to take place. Although it is preferable to begin the process as early as possible, there are issues that have to be sorted out before this can happen. Decisions need to be made regarding what project information can be released and what channels should be used for dissemination of information, and so on.

After the process begins, it is essential to maintain dialogue with the public and with the most directly affected groups (as evident in the Canada Line and City Link Melbourne projects). Finally, experiences and lessons learned from the process need to be properly captured (e.g. proper documentation and categorisation of findings from transcripts and videos from forums, written responses, survey results). Input of records into a database, which should be kept and updated by the client (that is relevant government departments for public infrastructure projects), for future reference can help project proponents and decision-makers of future projects better prepare for future public engagement processes.

\section{Conclusions}

Through reviews of existing practices and interviews with industry experts, challenges in public engagement for infrastructure projects in Hong Kong were identified. Inadequacy in public engagement was revealed through the XRL and Queen's Pier relocation projects. Although each project is unique, there are still common aspects and knowledge gained that can be applied to other similar projects.

Continuous engagement during the operation and usage phase was an important ingredient in the City Link Melbourne project, which employed various engagement methods for a diverse group of stakeholders, and provided a channel for the public to obtain information and express their comments and complaints with a formal resolution process. A comprehensive multi-staged public engagement plan, complemented by response tables showing how public comments were considered, contributed significantly to the success of the Canada Line project.

Based on the findings from this study, recommendations for enhancing public engagement practices and a roadmap for implementing these recommendations were presented. The findings have potential implications for rapidly developing cities, especially those with significant foreseeable construction works planned, such as Hong Kong and Singapore (Chief Executive Office of the Hong Kong SAR government, 2007; McKenna and Richardson, 1995; $\mathrm{Na}$ et al, 2006; Yuen, 2012). They may also be significant for cities hosting major international spectacles or sporting events, where construction work is being crammed into very tight windows (Baldwin, 2014; Barrow, 2012; Zimbalist, 2011). 


\section{Offprint provided courtesy of www.icevirtuallibrary.com Author copy for personal use, not for distribution}

Implementation of these recommendations will require strong determination and dedication towards a cultural change for the construction industry that places a higher emphasis on delivering long-term value to end-users and the general public. As a major client in infrastructure projects, relevant government departments must take the initiative in heading these reforms by setting mandates and/or protocols internally, as well as on contract requirements to engage community stakeholders proactively, initiate dialogue with them early in the project planning process, and improve transparency by making project information available in the public domain.

Promotion of public engagement guidelines and protocols for infrastructure projects from a construction industry coordination body can help to encourage consultants and contractors to become more actively involved with the process. Only with such concerted efforts and involvement from all the stakeholders can a culture of end-user value oriented practice be nurtured.

The recommendations are intended to help decision-makers and facilitators of public engagement events focus on critical aspects of public engagement and learn from past projects so that they can better anticipate and prepare for future projects.

For a region such as Hong Kong, with commitment from highlevel leadership to pursue a people-based approach to governance, it would only be natural and fitting to take a leap towards that goal by enhancing public engagement processes for major infrastructure projects so that the needs of society can be better addressed.

\section{References}

Anon (2007a) Death knell on pier. The Standard, 30 July.

Anon (2007b) Queen's Pier to be cut up and stored at month's end. The Standard, 19 July.

Anon (2010) 1,000 protesters stage Government House stand-off. South China Morning Post, 16 January.

Alexander E (2008) Public participation in planning - A multidimensional model: the case of Israel. Planning Theory and Practice 9(1): 57-80.

Baldwin A (2014) Stray Dogs a Problem for Sochi F1. Reuters, 20 February. See http://www.reuters.com/article/us-motor-racing-sochiidUSBREA1JOGW20140220 (accessed 08/04/2016).

Barrow A (2012) Scanning London's Olympic Stadium. Professional Surveyor Magazine 32(8), http://archives. profsurv.com/magazine/article. aspx?i=71156.

Broudehoux A (2007) Spectacular Beijing: the conspicuous construction of an Olympic Metropolis. Journal of Urban Affairs 29(4): 383-399.

Burnett M, Tsang S, Studer S, Hills P and Welford R (2008) Measuring trust in government: a Hong Kong perspective. International Public Management Review 9(2): 107-126.

CEDD (Civil Engineering and Development Department) (2013) Kai Tak development public consultation website. Civil Engineering and Development Department, last reviewed April 2013.

See http:// www.ktd.gov.hk/eng/public.html (accessed 27/03/2014).

Chief Executive Office of the Hong Kong SAR Government (2007) The 2007-08 Policy Address - A New Direction for Hong Kong. Hong Kong Special Administrative Region Government, Hong Kong, 10 October.

Chu C (2010) People power as exception: three controversies of privatization in post-handover Hong Kong. Urban Studies 47(8): 1773-1792.

Fedorovsky V, Kurillo S, Kryuchkov S et al. (2013) Geotechnical aspects of design and construction of the Mountain Cluster Olympic Facilities in Sochi. Proceedings of the 18th International Conference on Soil Mechanics and Geotechnical Engineering, Paris, France, 4: 3099-3102.

Government of Victoria (2008) Working Together: Involving Community and Stakeholders in Decision-Making. Office of Citizens and Civics: Consulting Citizens Series, Victoria Government, Victoria, Australia.
Hayllar MR (2010) Public-private partnerships in Hong Kong: good governance - the essential missing ingredient? The Australian Journal of Public Administration 69(1): 99-119.

HKSAR (Hong Kong Special Administrative Region Government) (2002) Appointments Herald New Era in Hong Kong's Governance. Press release 24 June 2002. See http://www.info.gov.hk/gia/general/brandhk/0624128.htm (accessed 05/04/2016).

HKSAR (2015) LCQ4: Official Elucidation on the Provisions of the Basic Law and Related Concepts. Press release 7 January 2015. See http://www.info.gov.hk/ gia/general/201501/07/P201501070433.htm (accessed 05/04/2016).

Hong Kong Legislative Council (2010) Panel on Transport - Subcommittee on Matters Relating to Railways Meeting on 16 April 2010. Hong Kong Legislative Council, Hong Kong.

InTransit BC (2006) Canada Line Traffic Management Strategy, February 2006. Transit BC, Province of British Columbia, Canada.

InTransit BC (2010) InTransit BC. See http://www.intransitbc.ca/about (accessed 21/11/2010)

Kaur J (2014) Public Private Partnership: Melbourne City Link, Australia. CUTS Institute for Regulation and Competition, New Delhi, India.

Kidd B (1992) The culture wars of the Montreal Olympics. International Review for the Sociology of Sport 27(2): 151-162.

Lam A (2009) Opponents of high-speed rail link claim victory as pan-democrats delay funding. South China Morning Post, 19 December.

Lenskyj HJ (1999) Sydney 2000, Olympic sport and the Australian media. Journal of Australian Studies 23(62): 76-83.

Lee K (2009) How the Hong Kong government lost the public trust in SARS insights for government communication in a health crisis. Public Relation Review 35(1): 74-76.

McKenna S and Richardson J (1995) Business values, management and conflict handling: issues in contemporary Singapore. Journal of Management Development 14(4): 56-70.

Mok (2010) Scholar of generation gaps looks past the post-80s. South China Morning Post, 17 January.

Na L, Ofori G and Park M (2006) Stimulating construction innovation in Singapore through the national system of innovation. Journal of Construction Engineering Management 132(10): 1069-1082.

Ormsby A (2011) 2012 Aquatics Construction Deadline Seen Tight. Reuters, 16 February. See $h$ ttp://in.reuters.com/article/idINIndia-54923420110216 (accessed 08/04/2016).

Parwani A (2007) Anger over plan to dismantle pier. South China Morning Post, 27 March.

Ravco (Richmond-Airport-Vancouver Rapid Transit) (2005) Responses to Environmental Assessment Certificate Application and Application Supplement Public Comments. RAV Project Management Ltd, British Columbia, Canada, 14 March.

Shan C and Yai T (2011) Public involvement requirements for infrastructure planning in China. Habitat International 35(1): 158-166.

The New York Times (2011) Economic Stimulus - Jobs Bills. See http://topics.nytimes.com/top/reference/timestopics/subjects/u/united_states economy/economic_stimulus/index.html (accessed 24/11/2011)

Transurban (2009) Transurban Sustainability Report 2009. Transurban Group, Melbourne, Australia.

Tsang S, Burnett M, Hills P and Welford R (2009) Trust, public participation and environmental governance in Hong Kong. Environmental Policy and Governance 19(2): 99-114.

Yuen J (2012) Building and Construction Industry in Hong Kong. Hong Kong Trade Development Council Research, Wanchai, Hong Kong, 19 November.

Yuen TWK and Greene M (2011) Impact of recent financial crisis on subjective perceptions of the economy: findings from Hong Kong, Guangdong, and Beijing. Chinese Economy 44(3): 45-58.

Yung EHK and Chan EHW (2011) Problem issues of public participation in built-heritage conservation: two controversial cases in Hong Kong. Habitat International 35(3): 457-466.

Zimbalist A (2011) Brazil's long to-do list. Americas Quarterly, summer issue. See http://www.americasquarterly.org/zimbalist (accessed 08/04/2016). 